Pesq. Vet. Bras. 37(8):847-852, agosto 2017 DOI: $10.1590 / \mathrm{S} 0100-736 \mathrm{X} 2017000800011$

\title{
Increased nitric oxide plasma concentration in dogs with naturally acquired chronic renal disease ${ }^{1}$
}

\author{
André B. Galvão ${ }^{2 *}$, Marileda B. Carvalho ${ }^{2}$, Luciane G. Batalhão ${ }^{3}$, Juliana C.B. Silva ${ }^{4}$, \\ Marcelo Batalhão $0^{5}$ and Evelin C. Carnio ${ }^{5}$
}

\begin{abstract}
Galvão A.B., Carvalho M.B., Batalhão L.G., Silva J.C.B., Batalhão M. \& Carnio E.C. 2017. Increased of nitric oxide plasma concentration in dogs with naturally acquired chronic renal disease. Pesquisa Veterinária Brasileira 37(8):847-852. Medicina Veterinária, Faculdade de Ciências Agrárias e Medicina Veterinária, Universidade Estadual Paulista, Via de Acesso Prof. Paulo Donato Castellane s/n, Jaboticabal, SP 14884-900, Brazil. E-mail: andrebgalvao@gmail.com

This study aimed to determine the amount of plasma nitric oxide in clinically stable dogs at different stages of chronic kidney disease (CKD). Five groups of dogs were studied, aged from 4 to 18, comprising of a control group composed of healthy animals (control $n=17$ ), group CKD stage 1 (DRC-1, n=12), group CKD stage 2 (CKD-2, $n=10$ ) group, CKD stages 3 (CRD-3, $n=13$ ) and Group CKD stage 4 (DRC-4, n=10). Dogs with CKD were clinically stable and received no treatment. Two blood samples were collected at 24 hours intervals (repeated measures) to obtain serum and plasma. The serum creatinine values were used to classify dogs as CG, CKD-1, CKD-2, CKD-3 and CKD-4, and were $(1.02 \pm 0.02 \mathrm{mg} / \mathrm{dL})$, $(1.07 \pm 0.04 \mathrm{mg} / \mathrm{dL}),(1.81 \pm 0.03 \mathrm{mg} / \mathrm{dL}),(3.40 \pm 0.15 \mathrm{mg} / \mathrm{dL})$ and $(6.00 \pm 0.20 \mathrm{mg} / \mathrm{dL}) \mathrm{respec}-$ tively. The determination of nitric oxide (NO) was performed by dosing nitrate/nitrite indirectly, and used for measurement of nitrate according to the NO/ozone chemiluminescence. The data were submitted to ANOVA for nonparametric analysis(Kruskal-Wallis) $(\mathrm{P}<0.05)$. The concentration of plasmatic NO did not differ significantly among GC $(10.81 \pm 0.51 \mu \mathrm{M})$, CKD-1 $(15.49 \pm 1.97 \mu \mathrm{M})$ and CKD-2 $(19.83 \pm 3.31 \mu \mathrm{M})$ groups. The plasma concentration of CKD-3 $(17.02 \pm 1.73 \mu \mathrm{M})$ and CKD-4 $(83.56 \pm 13.63 \mu \mathrm{M})$ was significantly higher compared with healthy dogs. In conclusion, the NO plasma concentration can increase in dogs with CKD and become significantly higher in stage 3 and 4 dogs.
\end{abstract}

INDEX TERMS: Nitric oxide plasma concentration, dog, chronic renal disease, azotemia, creatinine, proteinuria, hypertension.

RESUMO.- [Aumento da concentração plasmática de óxido nítrico em cães com doença renal crônica naturalmente adquirida.] A determinação de óxido nítrico no plasma em cães clinicamente estáveis em diferentes

\footnotetext{
${ }^{1}$ Received on May 26, 2016.

Accepted for publication on September 12, 2016.

${ }^{2}$ Programa de Pós-Graduação em Medicina Veterinária, Departamento de Clínica e Cirurgia Veterinária, Faculdade de Ciências Agrárias e Medicina Veterinária (FCAV), Universidade Estadual Paulista (Unesp), Via de acesso Prof. Paulo Donato Castellane s/n, Jaboticabal, SP 14884-900, Brazil. *Corresponding author: andrelgalvao@gmail.com

${ }^{3}$ Departamento de Morfologia e Fisiologia Animal, FCAV/Unesp, Via de acesso Prof. Paulo Donato Castellane s/n, Jaboticabal, SP 14884-900, Brazil.

${ }^{4}$ Embrapa Pantanal, Rua Vinte e Um de Setembro, Nossa Senhora de Fatima, Corumbá, MS 79320-900, Brazil.

${ }^{5}$ Escola de Enfermagem de Ribeirão Preto, Universidade de São Paulo (USP), Avenida dos Bandeirantes 3900, Ribeirão Preto, SP 14040-902, Brazil.
}

estágios da doença renal crônica (DRC) não foi estudada, constituindo este o objetivo do presente estudo. Foram estudados cinco grupos de cães, com idade variando entre quatro a 18 anos, compreendendo o grupo controle, composto por animais sadios (controle, $\mathrm{n}=17$ ), grupo com DRC estágio 1 (DRC-1, $\mathrm{n}=12$ ), grupo com DRC estágio 2 (DRC-2, $n=10$ ), grupo com DRC estágio 3 (DRC-3, n=13) e grupo com DRC estágio 4 (DRC-4, $n=10$ ). Os cães com DRC estavam com o quadro clínico estável e sem receber qualquer tipo de tratamento. Foram estudados cinco grupo de cães, com idade variando entre quatro a 18 anos, compreendendo o grupo controle, composto por animais sadios (controle, $\mathrm{n}=17$ ), grupo com DRC estágio 1 ( $\mathrm{DRC}-1, \mathrm{n}=12$ ), grupo com DRC estágio 2 (DRC-2, $\mathrm{n}=10$ ), grupo com DRC estágio 3 (DRC-3, n=13) e grupo com DRC estágio 4 (DRC-4, $\mathrm{n}=10$ ). Os animais sadios ou com DRC foram submetidos a 
duas coletas de sangue, com intervalo de 24 horas (amostras repetidas), para obtenção de soro e plasma. Os valores de creatinina sérica, que definiram a classificação dos pacientes do controle, DRC-1, DRC-2, DRC-3 e DRC-4, que foram $1,02 \pm 0,02 \mathrm{mg} / \mathrm{dL} ; 1,06 \pm 0,05 \mathrm{mg} / \mathrm{dL} ; 1,80 \pm 0,03 \mathrm{mg} / \mathrm{dL}$; $3,39 \pm 0,21 \mathrm{mg} / \mathrm{dL}$ e $6,00 \pm 0,28 \mathrm{mg} / \mathrm{dL}$, respectivamente. A determinação plasmática indireta de óxido nítrico (NO) foi realizada por meio da dosagem de nitrato/nitrito, através da técnia de quimioluminescência NO / ozono. Os dados foram submetidos à ANOVA para análise não paramétrica (Kruskal-Wallis) $(\mathrm{P}<0,05)$. Os resultados das concentrações plasmáticas de NO não diferiram significativamente quando comparados os dados do controle $(10,81 \pm 0,51 \mu \mathrm{M})$, DRC-1 $(15,49 \pm 1,97 \mu \mathrm{M})$, DRC-2 $(19,82 \pm 3,31 \mu \mathrm{M})$. No entanto, o NO plasmático do grupo DRC-3 $(17,01 \pm 1,73 \mu \mathrm{M})$ e DRC-4 $(83,55 \pm 13,63 \mu \mathrm{M})$, foi significativamente maior, em relação às médias dos cães sadios. Concluímos que a concentração plasmática de NO pode aumentar em cães com DRC e torna-se significativamente mais elevada nos estágios 3 e 4 da doença.

TERMOS DE INDEXAÇÃO: Concentração plasmática, óxido nítrico, cães, doença renal crônica, azotemia, creatinina, proteinuria, hipertensão.

\section{INTRODUCTION}

Chronic kidney disease (CKD) is defined as the presence of functional or structural abnormalities in the kidneys; it implies a 75\% reduction in the glomerular filtration rate (GFR) that typically corresponds to a loss of substantially more than $75 \%$ of the functional nephrons. Regardless of the cause or causes of nephron loss, CKD is characterized by irreversible structural lesions. Patients with CKD can be categorized into stages along a continuum of progressive kidney disease. The value of staging CKD is to facilitate application of appropriate clinical practice guidelines for diagnosis, prognosis and treatment. The IRIS (2013) has proposed a system for staging CKD in dogs and in cats. Regarding the renal condition, dogs can be classified as stage 0 , patients at risk of developing CKD. Patients with CKD can be categorized into four distinct stages according to clinical and laboratory data. For dogs in the first stage, the patient is not azotemic (serum creatinine $<1.4 \mathrm{mg} / \mathrm{dL}$ ); in the second stage the patient is characterized by mild renal azotemia (serum creatinine $1.4 \geq 2.0 \mathrm{mg} / \mathrm{dL}$ ) and clinical signs are usually mild or absent; in the third stage there is moderate renal azotemia (serum creatinine $\geq 2.1-5.0 \mathrm{mg} / \mathrm{dL}$ ) and clinical signs may be present; and in the fourth stage, the patient has severe renal azotemia (serum creatinine $>5.0 \mathrm{mg} /$ $\mathrm{dL}$ ) and clinical signs are usually present. It is also possible to establish subcategories within each stage, based on urinary protein excretion and arterial blood pressure. Patients are considered proteinuric when their protein/creatinine ratio (U-P/C) exceeds 0.5 . Patients may be classified as hypertensive with no complications when their systolic blood pressure (SBP) exceeds $160 \mathrm{mmHg}$ (Polzin et al. 2005, IRIS 2013).

Renal injury may be caused by activation of the renin-angiotensin, endothelin, and sympathetic nervous systems and a lack of vasodilatory action of nitric oxide (NO). The potent vasoconstrictor effect of NO deficiency causes decline in renal function and the non-hemodynamic actions of NO deficiency include permissive mesangial growth and matrix overproduction, promoting glomerular sclerosis (Aiello et al. 1997). The NO pathway has been implicated in many physiological functions in the kidney, including regulation of glomerular hemodynamics, mediation of pressure-natriuresis, maintenance of medullary perfusion, blunting of tubuloglomerular feedback, inhibition of tubular sodium reabsorption and modulation of renal sympathetic nerve activity (Polzin et al. 2005). These findings have clinical relevance, given the evidence that NO deficiency occurs in rats and humans as result of CKD. The deficiency the NO has been implicated in the hypertension and proteinuria in CKD (Aiello et al. 1997). However, determination of plasma in the NO in clinically stable dogs at different stages of naturally acquired CKD has not been studied, thus establishing the scope of this study.

\section{MATERIALS AND METHODS}

Ethics statement. The experiments were performed in accordance to the guidelines and practices of animal welfare established by the Animal Ethics Committee of Colégio Brasileiro de Experimentação Animal (CBEA) (Protocol 013690/11).

Animals. In this study, 62 adult dogs were evaluated from diverse races (28 females and 34 males). The patients were divided into 5 groups; the first group included 17 healthy dogs, which were included in the control group (CG) (serum creatinine $1.02 \pm 0.02 \mathrm{mg} / \mathrm{dL}$ ). The second group included $12 \mathrm{dogs}$ (serum creatinine $1.07 \pm 0.04 \mathrm{mg} / \mathrm{dL}$ ) in the CKD stage 1 group (CKD-1). The third group included 10 patients (serum creatinine $1.81 \pm 0.03 \mathrm{mg} /$ $\mathrm{dL}$ ) in the CKD stage 2 group (CKD-2). The fourth group included 13 dogs (serum creatinine $3.40 \pm 0.15 \mathrm{mg} / \mathrm{dL}$ ) in the CKD stage 3 group; and the fifth group included 10 dogs (serum creatinine $6.00 \pm 0.20 \mathrm{mg} / \mathrm{dL}$ ) in the CKD stage 4 group. The 45 dogs (19 females and 26 males) with clinically stable CKD and no treatment have been distributed according to the stage of CKD established by the IRIS (2013) as summarized in Table 1 . These five groups were formed by selected CKD adult dogs, without distinction of sex or breed, and no other unrelated primary concurrent disorder.

The exclusion criteria were: (a) diagnosis of acute kidney

Table 1. Characteristics of healthy dogs in control group and with CKD

\begin{tabular}{lccccc}
\hline Data & \multicolumn{5}{c}{ Group } \\
\cline { 2 - 6 } & CG & CKD-1 & CKD-2 & CKD-3 & CKD-4 \\
\hline $\mathrm{n}$ & 17 & 12 & 10 & 13 & 10 \\
Age (years)* & $9,0 \pm 0,85$ & $11,58 \pm 1,24$ & $10,50 \pm 1,16$ & $11,23 \pm 0,87$ & $9,9 \pm 1,00$ \\
Gender (male/ female) & $8 / 9$ & $6 / 6$ & $5 / 5$ & $11 / 2$ & $4 / 6$ \\
Body weight (kg)* & $20,89 \pm 3,09$ & $13,94 \pm 3,31$ & $15,78 \pm 3,20$ & $17,53 \pm 4,27$ & $27,38 \pm 4,24$ \\
* Mean \pm SEM. & & & & &
\end{tabular}


disease or lower urinary tract disease, (b) patient uremic crisis requiring immediate treatment or (c) insufficient sample volume obtained for all tests.

Experimental protocol. Once eligible for composing groups, healthy or CKD dogs were submitted to two assessment sessions with 24-hour intervals. Blood and urine samples were collected for analysis. Systolic blood pressure (SBP) was measured by Doppler vascular an indirect method (Doppler vascular DV10 microrem).

The blood samples were extracted from the right jugular vein to parameter determination of red blood cell count (RBC), hematocrit (HCT), mean corpuscular volume (MCV), mean corpuscular hemoglobin concentration (MCHC), platelet count (PLT) and white blood cell count (WBC), by a hematology automated analyzer (Coulter model ABC T8). At the same time the serum samples biochemical indices analysis were centrifuged at $2.000 \mathrm{~g}$ for $5 \mathrm{~min}$, and samples from the jugular vein collected in heparinized tube to analyze the nitric oxide levels, were centrifuged at $2.000 \mathrm{~g}$ for $20 \mathrm{~min}$ at $4^{\circ} \mathrm{C}$. The plasma was transferred to another tube and immediately frozen and stored at $-70^{\circ} \mathrm{C}$.

The urine sample was collected and analyzed for protein-creatinine ration $(\mathrm{U}-\mathrm{P} / \mathrm{C})$.

Serum samples were processed for the determination of creatinine (modified Jaffe method), urea (enzymatic method), total calcium (cresolphthalein complex one method) and phosphorus (method the phosphomolybdate). The urine samples were used for the determination of creatinine (modified Jaffe) and total protein (pyrogallol red method). All biochemical analysis were carried out with System Labtest sets of reagents. Semi-automatic spectrophotometer was used for the readings.

Serum sodium and potassium were measured by the method of ion-selective electrode.

Nitric oxide levels in plasma of clinically stabled dogs at different stages of naturally acquired CKD were evaluated indirectly by nitrite/nitrate quantification according to the technique described by Archer (1993). To determine plasma NO, the NO/ozone chemiluminescence technique was used, through a Sievers NO Analyzer 280 (GE Analytical Instrument, Boulder, CO, USA) and NO levels were expressed in $\mu \mathrm{M}$.
Statistical analysis. Statistical comparisons of differences in the responses were analyzed by ANOVA test followed by nonparametric analysis (Kruskal-Wallis). Differences in the mean values were considered significant at $(\mathrm{P}<0.05)$, using the GraphPad Prisma program.version 6.02 for Windows, GraphPad Software, La Jolla California USA.

\section{RESULTS}

Renal dysfunction was demonstrated by increased serum creatinine and urea levels, as well as increases on UPC mean of CKD groups, when compared to healthy dogs. On the other hand, the PLT count did not differ between CKD groups, when compared to healthy dogs. CKD dogs showed a significant rise in SBP compared to normal renal function dogs. RBC and HCT noticeably decreased in renal dysfunction dogs in comparison to normal renal functional dogs (Table 2).

\section{Nitric oxide levels}

The NO levels did not differ significantly $(P>0.05)$ between groups GC, CKD-1 and CKD-2. Nevertheless, the plasmatic group CKD-3 and CKD- 4 was significantly $(\mathrm{P}<0.05)$ higher compared to the mean of healthy dogs and CKD stages 1, 2 and control group (Table 3).

\section{DISCUSSION}

The L-arginine, traditionally considered a nutritionally dispensable (nonessential) amino acid, serves multiple functions, among them; it is the precursor of NO (Lau et al. 2000). It is formed from citrulline, which is a product of amino acid metabolism in the gut wall. L-arginine is converted from L-citrulline via argininosuccinate synthetase and argininosuccinate lyase predominantly in the proximal tubules of the kidney (Modlinger et al. 2004). There are many likely causes of NO deficiency in CKD, amongst them, limitations on substrate (L-Arginine) availability, probably

Table 2. Laboratory dates and systolic blood pressure (SBP) of comparison of healthy dogs in control group, and dogs CKD. The values are presented as the mean \pm standard error of the mean

\begin{tabular}{|c|c|c|c|c|c|}
\hline \multirow[t]{2}{*}{ Data } & \multicolumn{5}{|c|}{ Group } \\
\hline & CG & CKD-1 & CKD-2 & CKD-3 & CKD-4 \\
\hline $\mathrm{RBC}\left(\mathrm{x} 10^{6} / \mu \mathrm{L}\right)$ & $7,31 \pm 0,16^{\mathrm{a}}$ & $6,93 \pm 0,33^{a}$ & $6,17 \pm 0,22^{\mathrm{ab}}$ & $4,87 \pm 0,29^{b c}$ & $4,35 \pm 0,24^{c}$ \\
\hline $\operatorname{HCT}(\%)$ & $53,66 \pm 1,24^{\mathrm{a}}$ & $48,21 \pm 2,30^{\mathrm{ab}}$ & $43,85 \pm 1,65^{b c}$ & $36,54 \pm 1,97^{\mathrm{cd}}$ & $31,88 \pm 1,81 d$ \\
\hline $\operatorname{MCV}(\mathrm{fL})$ & $73,18 \pm 0,57^{a}$ & $71,79 \pm 0,78^{a}$ & $73,50 \pm 0,67^{a}$ & $73,85 \pm 0,46^{\mathrm{a}}$ & $72,00 \pm 0,77^{a}$ \\
\hline MCHC (g/dL) & $32,56 \pm 0,42^{\mathrm{a}}$ & $31,83 \pm 0,62^{a}$ & $33,40 \pm 0,54^{\mathrm{a}}$ & $33,74 \pm 0,47^{a}$ & $32,19 \pm 0,89^{a}$ \\
\hline PLT $\left(x 10^{6} / \mu \mathrm{L}\right)$ & $328,41 \pm 12,71^{a}$ & $315,33 \pm 18,55^{a}$ & $324,60 \pm 23,71^{\mathrm{a}}$ & $385,30 \pm 24,81^{\mathrm{a}}$ & $336,10 \pm 17,19^{a}$ \\
\hline $\mathrm{WBC}\left(\mathrm{x} 10^{3} / \mu \mathrm{L}\right)$ & $8,57 \pm 0,36^{b}$ & $8,36 \pm 0,49^{b}$ & $11,82 \pm 0,80^{\mathrm{a}}$ & $8,98 \pm 0,64^{\mathrm{ab}}$ & $10,48 \pm 1,00^{\mathrm{ab}}$ \\
\hline $\operatorname{Scr}(\mathrm{mg} / \mathrm{dL})$ & $1,02 \pm 0,02^{\mathrm{c}}$ & $1,07 \pm 0,04^{c}$ & $1,81 \pm 0,03^{b}$ & $3,40 \pm 0,15^{\mathrm{ab}}$ & $6,00 \pm 0,20^{\mathrm{a}}$ \\
\hline Sureia(mg/dL) & $31,18 \pm 1,73^{c}$ & $51,85 \pm 5,33^{\mathrm{cd}}$ & $80,17 \pm 11,2^{2 \mathrm{bd}}$ & $177,30 \pm 14,73^{a}$ & $223,10 \pm 11,23^{a}$ \\
\hline SCat (mg/dL) & $10,17 \pm 0,19^{c}$ & $10,37 \pm 0,18^{\mathrm{bc}}$ & $10,28 \pm 0,15^{b c}$ & $10,97 \pm 0,20^{\mathrm{ab}}$ & $11,52 \pm 0,30^{\mathrm{a}}$ \\
\hline $\mathrm{SP}(\mathrm{mg} / \mathrm{dL})$ & $4,16 \pm 0,16^{c}$ & $3,90 \pm 0,30^{c}$ & $5,28 \pm 0,36^{\mathrm{bc}}$ & $6,41 \pm 0,46^{\mathrm{ab}}$ & $8,26 \pm 0,73^{a}$ \\
\hline $\mathrm{SNa}(\mathrm{mEq} / \mathrm{L})$ & $148,10 \pm 0,42^{\mathrm{ab}}$ & $146,30 \pm 1,00^{\mathrm{b}}$ & $150,60 \pm 0,71^{\mathrm{a}}$ & $148,26 \pm 1,14^{\mathrm{ab}}$ & $146,70 \pm 0,87^{b}$ \\
\hline $\mathrm{SK}(\mathrm{mEq} / \mathrm{L})$ & $4,70 \pm 0,07^{\mathrm{ab}}$ & $4,60 \pm 0,10^{\mathrm{b}}$ & $4,20 \pm 0,09^{c}$ & $5,15 \pm 0,11^{\mathrm{a}}$ & $5,02 \pm 0,16^{\mathrm{ab}}$ \\
\hline $\mathrm{U}-\mathrm{P} / \mathrm{C}$ & $0,13 \pm 0,01^{\mathrm{c}}$ & $1,14 \pm 0,12^{b}$ & $0,59 \pm 0,16^{c}$ & $1,96 \pm 0,25^{\mathrm{ab}}$ & $1,53 \pm 0,25^{\mathrm{ab}}$ \\
\hline SBP (mmHg) & $137,9 \pm 1,9^{b}$ & $181,3 \pm 6,1^{\mathrm{a}}$ & $159,0 \pm 6,1^{\mathrm{ab}}$ & $186,9 \pm 6,1^{\mathrm{a}}$ & $180,0 \pm 7,3^{\mathrm{a}}$ \\
\hline
\end{tabular}

Averages in the same row, followed by at least one letter in common are not statistically different from each other (Kruskal-Wallis, $\mathrm{P}<0.05)$.

$\mathrm{RBC}=$ blood cell count, $\mathrm{HCT}=$ hematocritm, $\mathrm{MCV}=$ mean corpuscular volume, $\mathrm{MCHC}=$ mean corpuscular haemoglobin concentration, PLT = platelet count, WBC $=$ white blood cell count, $\mathrm{Scr}$ = serum creatinine, Sureia $=$ serum urea, $\mathrm{SCat}=$ serum total calcium, $\mathrm{SP}=$ serum phosphorus, $\mathrm{SNa}=$ serum sodium, serum potassium $=\mathrm{SK}, \mathrm{U}-\mathrm{P} / \mathrm{C}=$ protein $/$ creatinine ratio in urine, $\mathrm{SBP}=$ systolic blood pressure. 
Table 3. The nitric oxide (NO) levels of comparison of in dogs healthy controls, and dogs CKD. The values are presented as the mean \pm standard error of the mean

\begin{tabular}{lccccc}
\hline Data & \multicolumn{5}{c}{ Group } \\
\cline { 2 - 6 } & CG & CKD-1 & CKD-2 & CKD-3 & CKD-4 \\
\hline NO $(\mu \mathrm{M})$ & $10.81 \pm 0.51^{\mathrm{c}}$ & $15.49 \pm 1.97^{\mathrm{bc}}$ & $19,83 \pm 3,31^{\mathrm{bc}}$ & $17,02 \pm 1,73^{\mathrm{b}}$ & $83,56 \pm 13,63^{\mathrm{a}}$
\end{tabular}

Averages in the same row, followed by at least one letter in common are not statistically different from each other (Kruskal-Wallis, $\mathrm{P}<0.05$ ). $\mathrm{NO}=$ nitric oxide.

due to impaired renal L-Arginine biosynthesis, decreased transport of L-Arginine into endothelial cells and possible competition between NO synthase (NOS) and competing metabolic pathways, such as arginase (Archer 1993, Levillan et al. 2008). Surprisingly, total L-arginine synthesis is reportedly preserved in patients in end-stage renal disease. The plasma levels of L-arginine did not change significantly in rats with subtotal nephrectomy compared with normal rats (Levillan et al. 2008). This suggests that there was increased synthesis of L-arginine per nephron in the remaining renal mass and/or increased synthesis/ release of this amino acid at extra renal sites (Levillan et al. 2008). The remnant kidney undergoes hypertrophy after subtotal renal ablation. This may result in increased synthesis of L-arginine per nephron, an adaptive mechanism that attempts to maintain renal production of L-arginine at levels seen in rats with intact kidneys (Modlinger et al. 2004). The kidney is not the only organ of L-arginine synthesis. Experiments with dogs show that renal arginine synthesis accounts for the greater part of whole body arginine synthesis, but it is clear that $\sim 40 \%$ of this occurs outside the kidney (Modlinger et al. 2004). The sources of this extra renal arginine synthesis certainly includes arginine regeneration from citrulline produced in macrophages, intestine and endothelial cells (Yu et al. 1996).

In experimentally induced CKD caused by renal mass reduction, the combination of increased plasma citrulline concentration and proximal tubular hypertrophy can compensate and maintain renal L-arginine production (Modlinger et al. 2004, Levillan et al. 2008). Appreciable quantities of arginine are synthesized in the kidney from citrulline produced by the intestine (Levillan et al. 2008).

The quantitative importance of renal arginine synthesis in the humans was demonstrated by Tiazenello et al. (1980), who measured the net flux of amino acids across the kidney in normal subjects and in that chronic renal insufficiency. In normal subjects, renal arginine synthesis amounted to $\sim 1.75 \mathrm{~g} / \mathrm{d}$. Curiously, in the patients with chronic renal insufficiency, even GFR was reduced to $13 \%$ of normal, the kidneys still produced $\sim 0.7 \mathrm{~g}$ arginine/d. The reason for this is probably related to the elevation in plasma citrulline concentration seen in chronic renal insufficiency. The dog metabolism does not strongly differ from that of humans and might constitute an excellent experimental model when human kidneys are not available (Levillan et al. 2008). Yu et al. (1996) and Levillain et al. (2008) demonstrated that the dog arterial plasma exhibited appropriate levels of L-citrulline. Levillain et al. (2008) demonstrated that the dog production of L-arginine is proportional to the level of L-citrulline, the plasma concentrations of citrulline in dogs are sufficient to sustain a significant production of L-arginine for body needs as known in other species. These studies show that compensatory mechanisms can maintain adequate production of L-arginine and L-citrulline in dogs and in men, and may preserve NO production. Lau et al. (2000) studied the plasma levels of L-arginine and L-citrulline and examined the rate of whole body NO synthesis, using the stoichiometric reaction involving conversion of $\left[{ }^{15} \mathrm{~N}_{2}\right]$ arginine to $\left[{ }^{15} \mathrm{~N}\right]$ citrulline, in human patients with initial diagnosis of hypertension and end-stage renal disease clinically stable with no acute complications. As a result, it was demonstrated that the level of whole body L-arginine synthesis is maintained in human patients in end-stage renal disease, possibly due to an increase in the availability and adaptive volume citrulline. Furthermore, NO production in human patients in endstage renal disease was significantly increased when compared to healthy adults. Similar results were found, where all patients were clinically stable and without intercurrent acute illness; there was a significant increase in the plasma concentration of NO in dogs with end-stage renal disease compared with healthy dogs. Nevertheless, Wever et al. (1999) using L-[guanidine- ${ }^{-15} \mathrm{~N}_{2}$ ] arginine in a tracer paradigm comparable to the one used here for determination of NO production, reported a reduced rate of NO production in human patients with chronic renal failure who were not on hemodialysis and blood pressure controlled by antihypertensive therapy, NO production was monitored by measuring the isotopic enrichment of $\left[{ }^{15} \mathrm{~N}\right]$-citrulline in plasma during intravenous infusion of $\left[{ }^{15} \mathrm{~N}_{2}\right]$-arginine. Tatematsu et al. (2007) induced CKD through heminepherctomy and nephrectomy in male dogs and studied the nitrite/nitrate as a way to estimate the plasma NO concentration, and reported that plasma nitrite/nitrate levels decreased in the studied dogs, as well as the plasma NO even under the condition of TFG reduction. In this study, the authors attribute the plasma NO decrease to the fact that the dogs had not developed hypertension. Aiello et al. (1997) studied rats with CKD induced by renal mass reduction and demonstrated that unlike the kidney, the synthesis of NO increased in the systemic circulation, as reflected by higher than normal plasma nitrite/nitrate concentrations. In this study, an increase in the expression of iNOS and eNOS in endothelial cells of large vessels was found. However, the eNOS expression increase was not restricted to the endothelium but it was also detected in smooth muscle of large vessels. The authors believe that the probable cause for the increase in the production of $\mathrm{NO}$ in these sites is the increase in the blood flux tension force exerted in the vessels endothelium, which promotes mechanic-elastic alterations in the vessel and stimulates the eNOS expression. In this study the rats 
were hypertensive and as we know, in the HAS there is a pulsatile stretching of the arteries wall, which favors the NO synthesis. In addition to that, the rats were uremic which probably stimulated the iNOS expression through the action of inflammatory mediators such as TNF $\alpha$ (Aiello et al. 1997). Nava et al. (1998) studied the plasma NO concentration in the cardiovascular system of rats with spontaneous HAS and reported that the expression. of heart NOS and the micro vessels eNOS increased the NO production in such a way that the plasma nitrate concentration was significantly higher in hypertensive rats, when compared to healthy rats. Nevertheless, even with the NO increase, it is not vasoactive to stimulate an adequate vasodilation. These findings could justify the raised plasma levels of nitrate of our study, since our dogs with naturally acquired CKD in stage 1, 3 and 4 were hypertensive. Nevertheless, Yokokawa et al. (1995) demonstrated increased production of NO, determined by plasma nitrite and nitrate concentrations in human patients with end-stage renal disease and hemodialysis-induced hypotensive episodes. Komeno et al. (2004) studied the role of NO in hemodialysis-related hypotension in experimental renal dysfunction dog model, demonstrated in renal dysfunction dogs; a continuous hypotension occurred with a gradual increase in the plasma NO concentration. These results suggest that an excessive production of NO suppresses the sympathetic nerve activity in renal dysfunction dogs, according to the authors (Komeno et al. 2004).

Previous studies showed elevated plasma nitrite/nitrate levels in patients with end-stage renal disease, which was probably due to decreased excretion of nitrite/nitrate (Schmidt \& Baylis 2000). Blum et al. (1998) studied three groups of patients with different kidney function and conclude that renal nitrite/nitrate correlated with creatinine clearance. However, plasma nitrite/nitrate levels were higher than in healthy controls. The investigators conclude that end-stage renal disease is a state NO deficiency, but that $\mathrm{NO}_{2}$ and $\mathrm{NO}_{3}$ accumulate in the plasma because of decreased renal excretion. In our study, certainly the renal excretion of our patients was decreased, which might also justify the increased plasma concentration of NO.

Plasma L-arginine concentration is normal in patients with CKD although orotic acid increases which is indicative of net L-arginine deficiency. If L-arginine transport into endothelial cells was impaired in CKD, this would reduce the rate of removal of L-arginine from plasma and camouflage a reduction in intracellular L-arginine availability (Wagner et al. 2001). Studies with artificial solutions contenting high concentrations of urea suggest that urea contributes and that the effect is not osmotically mediated or acutely reversible with excess arginine and exhibits an "all-or-nothing" response, switching on when the concentration in the medium exceeds $\sim 15 \mathrm{mmmol} / \mathrm{L}$ or $\sim 45 \mathrm{mg} / 100 \mathrm{~mL}$ (Xiao et al. 2001). Furthermore, urea has to enter the endothelial cell to act, since in the presence of phloretin, a urea transport inhibitor, the inhibitory effect of urea on arginine transport was abolished. After 7 days of urea-induced inhibition of L-arginine transport, we observed decreased endothelial NOS (eNOS) activity in cultured endothelial cells, in the absence of changes in eNOS protein abundance, suggesting that cumulative substrate deficiency might lead to limitation of NO production (Xiao et al. 2001). However, in study by Aiello et al. (1997) in a rat model of CKD induced renal mass reduction found that, although there was decreased renal production of NO, there was an increase in total body. These investigations suggested that this up-regulation of vascular NOS activity might be caused by guanidinosuccinate, which is a toxin that accumulates in CKD humans and animals, and can increase NO production in cultured endothelial cells (Aiello et al. 1997). Such a finding also could account for the platelet dysfunction (Aiello et al. 1997). The authors suggest, that up-regulation of NO-forming enzymes might be an early defense mechanism against hypertension of uremia (Aiello et al. 1997). The patients in our study were at a condition of uremia, a condition that also may have promoted the enhanced levels of plasma NO.

Jankowski et al. (2007) and Lautner et al. (2013) have discovered a new component of the renin angiotensin system, named alamandina a peptide that increases with progression of CKD in rats, mice and humans. This peptide has vasodilating action by the increase of NO. In the present study, all patients were clinically stable, thus the increase of NO may be a defensive mechanism due to the various hemodynamic disorders caused by CKD. Research has demonstrated that the ability to convert nitrate/nitrite to NO, and the use of oral supplementation of sodium nitrate in humans resulted in decreased risk of developing cardiovascular disease, improvement in endothelial function, and vasodilatation (Carlström et al. 2011, Gilchrist et al. 2009).

\section{CONCLUSION}

The dogs with naturally acquired CKD presented higher NO plasma concentration concerning the values observed in healthy dogs. However, the differences are significant only in dogs in stages 3 and 4.

Acknowledgments.- This study was supported by FAPESP (Fundação de Amparo à Pesquisa do Estado de São Paulo, Proc. no 2011/08767-3).

Conflict of interest statement.- The authors have no competing interests.

\section{REFERENCES}

Aiello S., Noris M., Todeschini M., Zapella S., Foglieni G., Benigni A., Corna D.Z., Cavalloti D. \& Remuzzi G. 1997. Renal and systemic nitric oxide synthesis in rats with renal mass reduction. Kidney Int. 52:171-181.

Archer S. 1993. Measurement of nitric oxide in biological models. FASEB J. 1:349-360.

Blum M., Yachnin T., Wollman Y., Chernihovsky T., Peer G., Grosskopf I., Kaplan E., Silverberg D., Cabili S. \& Iaina A. 1998. Low nitric oxide production in patients with chronic renal failure. Nephron 79:265-268.

Carlström M., Persson A.E.G., Larsson E., Hezel M., Scheffer P.G., Teerlink T., Weitzberg E. \& Lundberg J.O. 2011. Dietary nitrate attenuates oxidative stress, prevents cardiac and renal injuries, and reduces blood pressure in salt-induced hypertension. Cardiovasc. Res. 89:574-585.

Gilchrist M., Winyard P.G. \& Benjamin N. 2009. Dietary nitrate: good or bad? Nitric Oxide 22:104-109.

IRIS 2013. International Renal Interest Society. Staging Chronic Kidney Disease (CKD) 2013. <http://www.irisiriskidney.com/pdf/IRISiris\%20 A4\%20Poster.pdf> Accessed Jan. 10, 2016.

Jankowski V., Vanholder R., Giet M.V.D., Karadogan S., Gobom J., Furket J., Oksche A., Krause E., Tran T.N.A., Tepel M., Schuchardt M., Schüter H., 
Wiedon A., Beyermann M., Bader M., Todiras M. \& Jankowski J. 2007. Mass-spectrometric identification of a novel angiotensin peptide in human plasma. Arterioscler. Thromb. Vasc. Biol, 27:297-302.

Komeno M., Akimoto A., Fujita T., Aramaki T., Aoki M., Shimada T. \& Ohashi F. 2004. Role of nitric oxide in hemodialysis - related hypotension in an experimental renal dysfunction dog model. J. Vet. Med. Sci. 66:53-57.

Lau T., Owen W., Yu Y. M., Novishi N., Lyons J., Zurakowsky D., Tsay R., Ajami A., Young Y. \& Castilho L. 2000. Arginine, citruline, and nitric oxide metabolism in end-stage disease patients. J. Clin. Invest. 105:1217-1225.

Lautner R.Q., Villela D.C., Fraga-Silva R., Silva N., Verano-Graga V., Costa-Fraga F., Jankowski V., Souza F.S., Alzamora A., Soares E., Kjedsen C.B., Oliveira A., Braga G., Savergninin S., Maia G., Peluso A., Passos-Silva D., Ferreira AF., Alves F., Martins A., Raizada M., Paula R., Motta-Santos D., Pimenta F.K.A., Alenina N., Sinisterra R., Bader M., Campagnole-Santos M.L. \& Santos R.A.S. 2013. Discovery and characterization of Alamandine - A novel component of the renin-angiotensin system. Cir. Res. 112:1104-1111.

Levillan O., Rabier D., Duclo B., Gaudreau P. \& Vinay P. 2008. L-argnine metabolism in dog kidney and isolated nephron segments. Metabolism 57:9-23.

Modlinger P.S., Wilcox C.S. \& Aslam S. 2004. Nitric oxide, oxidative stress, and progression of chronic renal failure. Semin. Nephrol. 24:354-365.

Nava E., Farre A., Moreno C.A., Santos C., Pierre M., Francesco C. \& Lüscher T.F. 1998. Alterations to the nitric oxide pathway in the spontaneously hypertensive rat. J. Hypertens. 16:609-615.

Polzin D.J., Osborne C.A. \& Ross S. 2005. Chronic renal failure, p.17561785. In: Ettnger S.J. \& Feldman E.C. (Eds), Textbook of Veterinary Internal Medicine. 6th ed. W.B. Saunders, Philadelphia.
Schmidt R.J. \& Baylis C. 2000. Total nitric oxide production is low in patients with chronic renal disease. Kidney Int, 58:1261-1266.

Tatematsu S., Wakino S., Kanda T., Homa K., Yoshioka K., Hasegawa K., Naoki S., Kimoto M., Saruta T. \& Hayachi K. 2007. Role of nitric oxide producing and degrading pathaways in coronary endothelial dysfunction in chronic kidney disease. J. Am. Soc. Nephrol.18:741-749.

Tiazenello A., Ferrari G., Gariboto G., Gurreri C. \& Robaudo C. 1980. Renal metabolism of amino acid and ammonia in subjects with normal renal function and in patients with chornic renal insufficiency. J. Clin. Invest. 65:1162-1173.

Wagner L., Klein J.D., Sands J.M. \& Baylis C. 2001. Urea transports are distributed in endothelial cells and mediate inhibition of L-arginine transport. Am. J. Physiol., Renal Physiol. 283:F578-F582.

Wever R., Boer P., Hijmering M., Stroes E., Verharr M., Kastelein J., Versluis K., Lagerwerf F., Herman R., Koomans H. \& Rabelink T. 1999. Nitric oxide production is reduced in patients with chronic renal failure. Arterioscler. Thromb. Vasc. Biol. 19:1168-1172.

Xiao S., Wagner L., Mahaney J. \& Baylis C. 2001. Uremic levels of urea inhibit L-arginine transport in cultered endothelial cells. Am. J. Physiol., Renal Physiol. 280:F989-F995.

Yokokawa K., Mankus R., Saklaven M.G., Kohno M., Yasunari K., Minami M., Kano H., Horio T., Takeda T. \& Mandel A.K. 1995. Increased nitric oxide production in patients with hypotension during hemodialysis. Ann. Intern. Med. 1:35-37.

Yu Y.M., Burker J.F., Tompkins R. \& Young V. 1996. Quantitative aspects of interorgan relation among arginine and ciltruline metabolism. Am. J. Physiol., End. Metabolism 34:E1098-E1109. 